\title{
THE AMINO ACID CONTENT OF THE BLOOD AND URINE IN WILSON'S DISEASE
}

\author{
By WILLIAM H. STEIN, A. G. BEARN, AND STANFORD MOORE \\ (From the Laboratories and the Hospital of the Rockefeller Institute for Medical Research, \\ New York, N. Y.)
}

(Submitted for publication September 2, 1953 ; accepted November 25, 1953)

Since the report of Uzman and Denny-Brown (1) that Wilson's disease was associated with an aminoaciduria, several studies of this aspect of the disease have appeared. Dent and Harris (2) employed paper chromatograms to demonstrate the generalized nature of the aminoaciduria, while Cooper, Eckhardt, Faloon, and Davidson (3) employed microbiological assay to determine quantitatively the extent of the excretion of eight essential and two non-essential amino acids. Investigations of the blood plasma by these investigators (3) and by Matthews, Milne, and Bell (4), who determined total $\alpha$-amino nitrogen, have not revealed any abnormalities in the concentration of amino acids in plasma, however. With the development of chromatographic methods employing columns of ion exchange resin, it has become possible to determine quantitatively and simultaneously the concentration of all of the ninhydrinpositive substances in normal and pathological urines (5) and in plasma (6). The application of these methods to a detailed study of the amino acid distribution in the urine and plasma of patients suffering from Wilson's disease forms the subject of this communication.

\section{MATERIALS AND METHODS}

Subjects. The subjects studied are described with the same initials and numbers in the preceding paper (7).

Samples of urine and blood. The collection of 24-hour urine specimens has already been described (7). For the collection of the urines from fasting individuals, the subject was instructed to void on arising and reject the specimen, drink about $300 \mathrm{cc}$. of water, void again after 1 to 2 hours and reject the specimen, drink an additional glass or two of water, and collect the urine during the ensuing 1 to 4-hour interval, the duration of which was recorded. The volume and specific gravity of the specimen were measured, and the urine concentrated in vacuo in a rotary evaporator (8) to a sufficiently small volume to raise the specific gravity to about 1.02 to 1.03 . Usually, $2 \mathrm{cc}$. aliquots of samples of urine from patients with Wilson's disease ( $3 \mathrm{cc}$. of fasting urine) were taken for analysis. Urine was hydrolyzed in the manner already described (5).

Blood was drawn into heparinized tubes and $10 \mathrm{cc}$. aliquots of plasma deproteinized with picric acid and prepared for chromatography in the manner described for normal plasma (6).

Chromatographic analyses. The results given in Tables I and II were obtained by chromatographing the urine on $100 \mathrm{~cm}$. columns of Dowex 50 (8 per cent cross-linking) and on $15 \mathrm{~cm}$. columns exactly as already outlined (9). The remaining data on urine (Tables IV and V), and all the data on plasma were obtained by the use of the modified ion exchange method (10) employing $150 \mathrm{~cm}$. columns of 4 per cent cross-linked Dowex 50. In most cases only a single chromatographic analysis was run for each sample of urine or plasma. Identification of the peaks on the urine curve (Figure 1) was accomplished by the use of the three criteria already discussed for the case of normal urine (5).

\section{RESULTS}

\section{The amino acid content of urine}

A typical elution curve obtained when an aliquot of a 24-hour urine specimen from a patient with Wilson's disease is chromatographed on Dowex 50 is given as the solid line in Figure 1. For comparison, a curve from normal urine taken from previous work (5) is shown as the broken line. The quantitative extent of the aminoaciduria in Wilson's disease can be determined from the data presented in Table I, which indicate that the total daily excretion of most of the amino acids is markedly elevated in many cases. Moreover, two amino acids not present in normal urine in detectable amounts, namely, citrulline and proline, may be found in Wilson's disease. Proline is not listed in Table I because it partially overlaps citrulline with the system shown in Figure 1. This overlap does not interfere with the determination of citrulline for the reason that proline yields a yellow colored compound with ninhydrin which absorbs maximally at $440 \mathrm{~m} \mu$ and contributes only a negligible amount of absorption at $570 \mathrm{~m} \mu$. The citrul- 
line color, which absorbs maximally at $570 \mathrm{~m} \mu$, almost completely masks the proline compound, however, making it impossible to obtain quantitative data for the latter. The presence of large amounts of proline was readily established when the fractions from the citrulline peak were chromatographed on paper strips. A prominent yellow spot in the proline position was clearly separated from the bluish-brown citrulline spot. Furthermore, when a sample of urine was chromatographed on a column of 4 per cent cross-linked Dowex 50, under conditions where proline and citrulline are well separated, a large proline peak was obtained corresponding to an excretion of about $175 \mathrm{mg}$. of proline per day.

With the chromatographic system employed for the experiments given in Tables III to VI, citrulline and glycine are not separated and hence are determined together.

Several points of interest emerge when the data in Table I, excluding Patient 2 who will be discussed later, are considered as a whole. The highest levels of excretion relative to the normal are reached by threonine and cystine, which may be elevated twenty-fold. The large amount of threonine in Wilson's disease urine was also noted by Cooper, Eckhardt, Faloon, and Davidson (3). The quantities of serine, glycine, asparagine + glutamine, valine, tyrosine, and lysine may increase 5 to 10 fold, while the amounts of histidine, ornithine, and phenylalanine may rise to 2 to 4 times the normal level. The quantities of amino-

TABLE I

The amino acid content of urine in Wilson's disease *

\begin{tabular}{|c|c|c|c|c|c|c|c|}
\hline \multirow[b]{2}{*}{ Amino acid } & \multicolumn{6}{|c|}{ Patient } & \multirow[b]{2}{*}{$\begin{array}{c}\text { Normal } \\
\text { range }\end{array}$} \\
\hline & C. ${ }^{1}$. & $\mathrm{V}^{2} \cdot \mathrm{R}$. & J. $\stackrel{3}{\mathbf{M}}$ & G. V. & $\begin{array}{c}5 \\
\text { L. A. }\end{array}$ & w. c. & \\
\hline $\begin{array}{l}\text { Glutamine }+ \text { asparagine } \$ \ddagger \\
\text { Aspartic } \\
\text { Glutamic } \\
\text { Glycine } \\
\text { Alanine + aminoadipic } \$ \\
\text { Valine } \\
\text { Leucine } \\
\text { Isoleucine } \\
\text { Serine } \dagger \\
\text { Threonine } \\
\text { Cystine } \\
\text { Methionine } \\
\text { Taurine } \\
\text { Phenylalanine } \\
\text { Tyrosine } \\
\text { Histidine \| } \\
\text { 1-methylhistidine \| } \\
\text { Citrulline } \\
\text { Ornithine \| } \\
\text { Lysine \| } \\
\text { Arginine | }\end{array}$ & $\begin{array}{r}390 \\
<10 \\
58 \\
520 \\
230 \\
37 \\
36 \\
26 \\
275 \\
440 \\
220 \\
12 \\
85 \\
50 \\
160 \\
500 \\
47 \\
81 \\
13 \\
200 \\
10\end{array}$ & $\begin{array}{r}130 \\
<10 \\
21 \\
220 \\
74 \\
6 \\
15 \\
13 \\
95 \\
82 \\
50 \\
5 \\
120 \\
20 \\
45 \\
270 \\
38 \\
10 \\
5 \\
33 \\
10\end{array}$ & $\begin{array}{r}680 \\
<10 \\
100 \\
960 \\
380 \\
55 \\
60 \\
24 \\
490 \\
680 \\
330 \\
30 \\
46 \\
110 \\
380 \\
650 \\
26 \\
210 \\
37 \\
380 \\
34\end{array}$ & $\begin{array}{r}395 \\
<10 \\
30 \\
530 \\
220 \\
35 \\
42 \\
37 \\
285 \\
490 \\
220 \\
5 \\
140 \\
60 \\
140 \\
450 \\
140 \\
140 \\
33 \\
230 \\
10\end{array}$ & $\begin{array}{r}710 \\
<10 \\
110 \\
900 \\
490 \\
110 \\
65 \\
66 \\
510 \\
860 \\
770 \\
5 \\
130 \\
120 \\
270 \\
680 \\
77 \\
440 \\
130 \\
860 \\
160\end{array}$ & $\begin{array}{r}590 \\
<10 \\
87 \\
550 \\
230 \\
63 \\
25 \\
28 \\
425 \\
580 \\
120 \\
17 \\
49 \\
120 \\
420 \\
580 \\
42 \\
190 \\
5 \\
79 \\
10\end{array}$ & $\begin{array}{c}40-100 \\
<10 \\
<10 \\
70-200 \\
20-70 \\
<10 \\
10-25 \\
10-30 \\
25-75 \\
15-50 \\
<10-20 \\
<10 \\
85-300 \\
10-30 \\
15-50 \\
110-320 \\
50-210 \\
<10 \\
<10 \\
10-50 \\
<10\end{array}$ \\
\hline Total & 3365 & 1225 & 5660 & 4290 & 7480 & 4195 & $800-1200$ \\
\hline $\begin{array}{l}\text { Urine volume, ml. } \\
\text { Total N excreted, Gm. } \\
\text { Total } \alpha \text {-amino N, mg. }\end{array}$ & $\begin{array}{r}1540 \\
13.86\end{array}$ & $\frac{930}{-}$ & $\begin{array}{l}1380 \\
8.00\end{array}$ & $\begin{array}{r}2220 \\
12.75\end{array}$ & $\begin{array}{r}2300 \\
16.70\end{array}$ & $\begin{array}{r}2830 \\
11.97\end{array}$ & $1000-2000$ \\
\hline From columns & $\begin{array}{l}393 \\
551\end{array}$ & $\begin{array}{l}137 \\
211\end{array}$ & $\begin{array}{l}673 \\
842\end{array}$ & $\begin{array}{l}416 \\
522\end{array}$ & $\begin{array}{r}552 \\
1055\end{array}$ & $\begin{array}{l}479 \\
612\end{array}$ & $100-160$ \\
\hline
\end{tabular}

* The amounts excreted are reported in mg. per day. The diets were not controlled.

f In every case the quantity of serine + glutamine + asparagine was determined by chromatograms of the type shown in Figure 1. In one instance serine was separated from glutamine + asparagine by chromatography on 4 per cent cross-linked Dowex $\mathbf{5 0}$ and found to be comprised of about $\mathbf{5 0}$ per cent of the total on a molar basis. A similar ratio of serine to glutamine + asparagine was found for normal subjects (5). All of the individual values for serine and for glutamine + asparagine are, therefore, calculated on this basis.

$\ddagger$ Calculated as glutamine.

Calculated as alanine. In one case chromatography on 4 per cent cross-linked Dowex 50 (10) revealed the absence of significant quantities of aminoadipic acid.

If Minimal values. Quantitative recoveries of the basic amino acids are not obtained in experiments of the type shown in Figure 1. 
TABLE II

Amino acid content of acid hydrolysates of urine in Wilson's disease

\begin{tabular}{|c|c|c|c|c|c|c|}
\hline \multirow[b]{3}{*}{ Amino acid } & \multicolumn{6}{|c|}{ Amount excreted, mg. per day } \\
\hline & \multicolumn{3}{|c|}{ Total after hydrolysis } & \multicolumn{3}{|c|}{ Increase after hydrolysis } \\
\hline & Patient 3 & Patient 4 & Patient 5 & Patient 3 & Patient 4 & Patient 5 \\
\hline $\begin{array}{l}\text { Aspartic } \\
\text { Glutamic } \\
\text { Glycine } \\
\text { Alanine } \\
\text { Valine } \\
\text { Leucine } \\
\text { Isoleucine } \\
\text { Serine } \\
\text { Threonine } \\
\text { Cystine } \\
\text { Taurine } \\
\text { Phenylalanine } \\
\text { Tyrosine } \\
\text { Histidine } \\
\text { 1-methylhistidine } \\
\text { Citrulline } \\
\text { Ornithine } \\
\text { Lysine } \\
\text { Arginine }\end{array}$ & $\begin{array}{r}650 \\
1890 \\
1290 \\
515 \\
115 \\
120 \\
65 \\
620 \\
620 \\
305 \\
54 \\
140 \\
420 \\
560 \\
30 \\
150 \\
85 \\
435\end{array}$ & $\begin{array}{r}510 \\
1210 \\
975 \\
290 \\
110 \\
130 \\
70 \\
410 \\
550 \\
285 \\
130 \\
110 \\
195 \\
475 \\
175 \\
121 \\
75 \\
335 \\
85\end{array}$ & $\begin{array}{r}1135 \\
1810 \\
820 \\
305 \\
250 \\
145 \\
740 \\
1010 \\
700 \\
135 \\
235 \\
350 \\
720 \\
70 \\
7190 \\
965 \\
65\end{array}$ & $\begin{array}{r}650 \\
1790 \\
330 \\
135 \\
60 \\
60 \\
41 \\
130 \\
-60 \\
-25 \\
8 \\
30 \\
40 \\
-90 \\
4 \\
-60 \\
48 \\
55\end{array}$ & $\begin{array}{r}510 \\
1180 \\
445 \\
70 \\
75 \\
88 \\
33 \\
125 \\
60 \\
65 \\
-10 \\
50 \\
55 \\
25 \\
35 \\
-20 \\
42 \\
105 \\
75\end{array}$ & $\begin{array}{r}1135 \\
-910 \\
330 \\
195 \\
185 \\
79 \\
230 \\
150 \\
-70 \\
5 \\
115 \\
80 \\
40 \\
-7 \\
-60 \\
105 \\
-95\end{array}$ \\
\hline Total & 8064 & 6241 & & 3146 & 3008 & \\
\hline
\end{tabular}

* Uncorrected for aminoadipic acid.

adipic acid, methionine, isoleucine, leucine, and arginine seem to be the least abnormal. On the average, there appears to be a diminished excretion of taurine and of l-methylhistidine, and separate

TABLE III

Amino acid content of fasting plasma in Wilson's disease

\begin{tabular}{lccc}
\hline & \multicolumn{2}{c}{$\begin{array}{c}\text { Mg. amino acid per } \\
\text { 100 cc. plasma }\end{array}$} & \\
\cline { 2 - 3 } \multicolumn{1}{c}{ Amino acid } & $\begin{array}{c}\text { Patient } 9 \\
\text { M.G. }\end{array}$ & $\begin{array}{c}\text { Patient } 7 \\
\text { C.P. }\end{array}$ & $\begin{array}{c}\text { Normal } \\
\text { range }\end{array}$ \\
\hline Glutamic acid & 0.55 & 0.65 & $0.4-1.2$ \\
Glycine + citrulline * & 2.31 & 1.55 & $1.5-2.0$ \\
Alanine & 2.98 & 2.20 & $3.0-3.7$ \\
Aminobutyric acid & 0.09 & 0.22 & $0.2-0.35$ \\
Valine & 2.05 & 2.51 & $2.3-3.7$ \\
Leucine & 1.48 & 1.48 & $1.4-2.3$ \\
Isoleucine & 0.85 & 0.73 & $0.7-1.3$ \\
Serine & 0.85 & 0.87 & $1.0-1.3$ \\
Threonine & 1.55 & 1.11 & $1.2-1.7$ \\
Half-cystine & 1.57 & 1.39 & $1.0-1.3$ \\
Methionine & 0.44 & 0.30 & $0.3-0.4$ \\
Taurine & 0.31 & 0.26 & $0.4-0.8$ \\
Proline & 2.94 & 1.64 & $1.8-3.3$ \\
Phenylalanine & 1.09 & 0.98 & $0.7-1.0$ \\
Tyrosine & 1.58 & 0.93 & $0.8-1.5$ \\
Histidine & 1.40 & 0.91 & $0.8-1.5$ \\
Ornithine & 0.91 & 0.78 & $0.6-0.8$ \\
Lysine & 2.00 & 2.65 & $2.5-3.0$ \\
Arginine & 0.97 & 1.07 & $1.2-2.0$ \\
\multicolumn{1}{c}{ Total } & & & \\
\hline
\end{tabular}

* Calculated as glycine. Assuming a citrulline value of $0.50 \mathrm{mg}$. per $100 \mathrm{cc}$., as reported by Archibald (21) for normal fasting plasma, the glycine content would be about $0.20 \mathrm{mg}$. per $100 \mathrm{cc}$. less than the figures given.
$15 \mathrm{~cm}$. columns run with several urine specimens revealed that 3-methylhistidine (11) was sometimes absent altogether.

Patient 2, a sibling of Patient 1, is unique in that the excretion of most amino acids is in the high normal range. Those amino acids excreted in largest amount, however, are the same that are the most abnormal in the other patients, namely, threonine, cystine, serine, glycine, and asparagine + glutamine. The next highest are alanine, tyrosine, and histidine.

In Patient 5, the total output of amino acids per day is the highest listed. The amount of cystine, lysine, ornithine, and arginine excreted, however, is, relative to the others, the most increased. The levels of these same four amino acids are found to be markedly elevated in cystinuria $(12,13)$.

The data in Table I show that the total alphaamino nitrogen accounted for as individual amino acids on the chromatograms is always less than that determined directly by the ninhydrin method of Van Slyke, MacFadyen, and Hamilton (14). The total derived from the column may be expected to be low for several reasons. In the first place, proline, which probably contributes 10 to $20 \mathrm{mg}$. of alpha-amino nitrogen, is not listed in Table $\mathrm{I}$. In the second place, glutamine is very unstable and over 50 per cent of it is transformed to pyrrolidone 

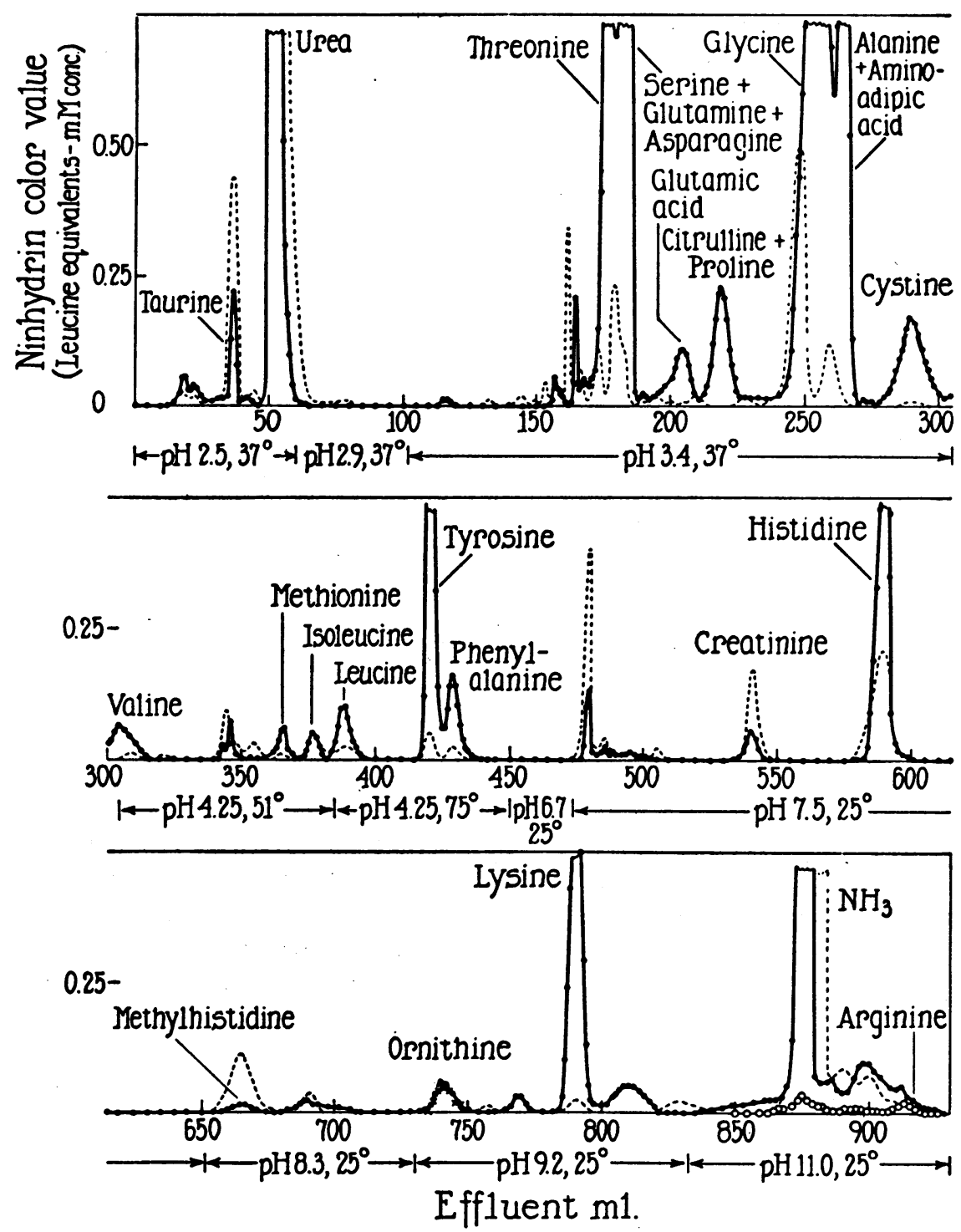

Fig. 1. Chromatographic Separation of Amino Acids from the Urine of a Patient with Wilson's Disease, Patient 3, Table I (Solid Line)

The column of Dowex 50 (about 8 per cent cross-linking), $0.9 \times 100 \mathrm{~cm}$., was operated in the sodium form, with buffers of the $\mathrm{pH}$ and temperature indicated as eluants. A sample of 2 cc. of urine was chromatographed. The broken line is the curve obtained previously (5) with normal urine. The crosses in the ornithine peak represent the results obtained by the colorimetric method of Chinard (20). The open circles under the ammonia peak indicate the quantity of ninhydrin-positive material in these alkaline fractions after they had been exposed to reduced pressure to remove ammonia.

carboxylic acid during chromatography and is not determined. Since it can be estimated that at least one half of the glutamine + asparagine peak is actually glutamine, the total quantity of alpha amino nitrogen arising from this source is probably at least half again greater than would be in- dicated by the figures in Table I. Finally, columns of the type used in these experiments give low recoveries for the basic amino acids, histidine, the methylhistidines, ornithine, lysine, and arginine. The extent of the losses can be estimated roughly from earlier work (cf. [9] Table II). 
The values obtained by the ninhydrin method of Van Slyke, MacFadyen, and Hamilton (14) will be too high because cystine evolves about 2 equivalents of $\mathrm{CO}_{2}$ per amino group and many of the urine specimens are rich in cystine. Taking all these factors into account, the chromatograms appear to account for about 90 per cent of the total alpha amino nitrogen in Patients 1, 3, and 4, 80 per cent in Patients 2 and 6 , and 70 per cent in $\mathrm{Pa}$ tient 5.

Like normal urine, the urine of patients with Wilson's disease contains amino acids in conjugated linkages from which the free amino acids are liberated by hydrolysis with acid. A total of about $3 \mathrm{Gm}$. of amino acids appeared after acid hydrolysis of two urine specimens (Table II), a quantity about double that obtained from normal urine (5). There is thus a smaller proportional elevation in the amount of conjugated amino acids than in the amount of the free amino acids. Certain amino acids, such as serine, threonine, citrulline, cystine, tyrosine, and histidine decompose

TABLE IV

Effect of protein intake on the level of urinary amino acids in a single normal subject *

\begin{tabular}{|c|c|c|c|}
\hline \multirow[b]{2}{*}{ Amino acid } & \multicolumn{3}{|c|}{ Level of dietary protein } \\
\hline & $15 \mathrm{Gm}$. & $70 \mathrm{Gm}$. & $200 \mathrm{Gm}$. \\
\hline $\begin{array}{l}\text { Glutamic acid } \\
\text { Aminoadipic acid } \\
\text { Glycine } \\
\text { Alanine } \\
\text { Valine } \\
\text { Leucine } \\
\text { Isoleucine } \\
\text { Serine } \\
\text { Threonine } \\
\text { Half-cystine } \\
\text { Taurine } \\
\text { Prcline } \\
\text { Phenylalanine } \\
\text { Tyrosine } \\
\text { Histidine } \dagger \\
\text { 1-methylhistidine } \\
\text { 3-methylhistidine } \\
\text { Ornithine } \\
\text { Lysine } \\
\text { Arginine }\end{array}$ & $\begin{array}{r}66 \\
5 \\
44 \\
13 \\
6 \\
3 \\
9 \\
25 \\
14 \\
9 \\
95 \\
<10 \\
8 \\
16\end{array}$ & $\begin{array}{r}6 \\
12 \\
- \\
9 \\
6 \\
17 \\
33 \\
21 \\
13 \\
141 \\
<10 \\
14 \\
22\end{array}$ & $\begin{array}{r}7 \\
33 \\
98 \\
35 \\
20 \\
14 \\
41 \\
57 \\
34 \\
20 \\
163 \\
<10 \\
17 \\
49\end{array}$ \\
\hline Total & $344 \nmid$ & $\ddagger$ & $930 \uparrow$ \\
\hline $\begin{array}{l}\text { Urine vol., ml. } \\
\text { Total N, Gm. }\end{array}$ & $\begin{array}{r}520 \\
5.1\end{array}$ & $\begin{array}{l}670 \\
8.6\end{array}$ & $\begin{array}{r}1280 \\
23.4\end{array}$ \\
\hline
\end{tabular}

* Excretion given in mg. of amino acids per day.

$t$ Histidine was not determined in these chromatograms because of overlaps with creatinine. The total values will therefore be low by about 100 to $300 \mathrm{mg}$.

$\ddagger$ The determinations of glycine and alanine were lost in this case, and hence the total would not be meaningful. partially on acid hydrolysis, thus accounting for the loss in some of these amino acids (cf. Table II). The amounts of aspartic and glutamic acids increase the most after hydrolysis, a considerable proportion of the increase doubtless arising as a result of the decomposition of asparagine and glutamine. Conjugated glycine, part of which comes from hippuric acid, despite its great quantity, is at or below normal levels. Taurine, citrulline, histidine, and 1-methylhistidine, on the other hand, do not increase in amount after hydrolysis, and hence appear to exist largely in the free form. Conjugated forms of all of the other amino acids seem to exist in urine from patients with Wilson's disease, and in quantities exceeding the normal. The nature, the origin, and the function of many of the conjugated amino acids of urine is not known (cf. [5]). In the investigation of this problem, urine from patients with Wilson's disease may prove to be a useful source of conjugated amino acids.

\section{The amino acid content of plasma}

The result of the chromatography of a sample of fasting plasma from a patient with Wilson's disease is shown in Figure 2. Qualitatively, the picture appears normal (cf. [6]), an impression confirmed by the quantitative data given in Table III. When compared to the normal range given in the last column of the table, which is based on only five individuals (6), none of the amino acid values is significantly aberrant for both patients; nor do the total quantities of amino acids ${ }^{1}$ given at the bottom of the table reveal any noteworthy or consistent trends. Thus, the observation of Cooper, Eckhardt, Faloon, and Davidson (3) based on the ninhydrin method of Van Slyke, MacFadyen, and Hamilton (14) that the total alpha amino nitrogen in fasting plasma in Wilson's disease is normal is confirmed, and supplemented by the finding that the detailed amino acid distribution is also normal.

\section{The effect of diet upon the levels of amino acids in urine and plasma}

There is evidence in the literature $(3,15,16)$ based on alpha amino nitrogen determinations and

1 Glutamine, asparagine, and tryptophan were not determined in these plasmas, so that the totals given in the table are probably about $8 \mathrm{mg}$. per cent too low. 
microbiological assay that neither the total quantity nor the distribution of amino acids in normal urine can be correlated closely with the dietary intake of protein. This fact has been further established in the present investigations by two types of experiments. In the first, a normal individual was maintained for one week intervals on diets containing $15 \mathrm{Gm}$., $70 \mathrm{Gm}$., and $200 \mathrm{Gm}$. of protein, and aliquots of 24-hour urine samples taken during the middle of the experimental period were chromatographed (Table IV). A 13-fold increase in dietary protein causes, for the most part, a 2 or a 3-fold increase in the excretion of any individual amino acid (1-methylhistidine excepted). Moreover, the total quantity of amino acids excreted also only doubles, if the contribution of 1-methylhistidine is neglected. 1-Methylhistidine is the only amino acid the excretion of which in these experiments reflects in a roughly linear fashion the level of protein in the diet.

Evidence for a lack of dependence of the level of urinary amino acids upon the amount of protein ingested is afforded by analyses of normal fasting and normal post-prandial urine. In two instances,

TABLE V

Effect of a casein meal upon the amino acid levels of the urine in Wilson's disease

\begin{tabular}{|c|c|c|c|}
\hline \multirow[b]{2}{*}{ Amino acid } & \multicolumn{3}{|c|}{$\begin{array}{l}\text { Urine levels calculated as mg. amino } \\
\text { acid excreted per } 24 \mathrm{hrs} \text {. }\end{array}$} \\
\hline & $\begin{array}{l}\text { Fasting } \\
\text { Patient } 9\end{array}$ & $\begin{array}{l}\text { Fasting* } \\
\text { Patient } 7\end{array}$ & $\begin{array}{c}\text { Post } \\
\text { proteint } \\
\text { Patient } 7\end{array}$ \\
\hline $\begin{array}{l}\text { Asparagine } \\
\text { Glutamic acid } \\
\text { Aminoadipic acid } \\
\text { Glycine + citrulline f } \\
\text { Alanine } \\
\text { Aminobutyric acid } \\
\text { Valine } \\
\text { Leucine } \\
\text { Isoleucine } \\
\text { Serine } \\
\text { Threonine } \\
\text { Half-cystine } \\
\text { Methionine } \\
\text { Taurine } \\
\text { Proline } \\
\text { Phenylalanine } \\
\text { Tyrosine } \\
\text { Histidine } \\
\text { 1-methylhistidine } \\
\text { 3-methylhistidine } \\
\text { Ornithine } \\
\text { Lysine } \\
\text { Arginine }\end{array}$ & $\begin{array}{r}204 \\
30 \\
7 \\
596 \\
190 \\
<10 \\
14 \\
28 \\
14 \\
338 \\
379 \\
124 \\
<10 \\
34 \\
<10 \\
38 \\
144 \\
500 \\
<10 \\
42 \\
13 \\
116 \\
8\end{array}$ & $\begin{array}{r}104 \\
6 \\
12 \\
328 \\
60 \\
<10 \\
6 \\
20 \\
12 \\
173 \\
141 \\
41 \\
<10 \\
8 \\
<10 \\
19 \\
48 \\
286 \\
38 \\
40 \\
<10 \\
53 \\
5\end{array}$ & $\begin{array}{r}314 \\
31 \\
45 \\
586 \\
434 \\
12 \\
230 \\
152 \\
53 \\
550 \\
600 \\
117 \\
29 \\
20 \\
197 \\
110 \\
480 \\
516 \\
55 \\
33 \\
<10 \\
395 \\
165\end{array}$ \\
\hline
\end{tabular}

* Urine volume, $350 \mathrm{cc}$. in 4 hours.

t Urine volume, $780 \mathrm{cc}$. in 3 hours.

₹ Calculated as glycine.
TABLE VI

The effect of a casein meal upon the amino acid levels in the plasma of a normal individual and a patient with Wilson's disease

\begin{tabular}{|c|c|c|c|c|}
\hline \multirow[b]{3}{*}{ Amino acid } & \multicolumn{4}{|c|}{ Plasma levels in mg. of amino acid per $100 \mathrm{cc}$} \\
\hline & \multicolumn{2}{|c|}{ Post protein } & \multicolumn{2}{|c|}{$\begin{array}{c}\text { Increase after } \\
\text { protein }\end{array}$} \\
\hline & Normal & Patient 7 & Normal & Patient ? \\
\hline $\begin{array}{l}\text { Asparagine } \\
\text { Glutamic acid } \\
\text { Aminoadipic acid } \\
\text { Glycine + citrulline* } \\
\text { Alanine } \\
\text { Aminobutyric acid } \\
\text { Valine } \\
\text { Leucine } \\
\text { Isoleucine } \\
\text { Serine } \\
\text { Threonine } \\
\text { Half-cystine } \\
\text { Methionine } \\
\text { Taurine } \\
\text { Proline } \\
\text { Phenylalanine } \\
\text { Tyrosine } \\
\text { Histidine } \\
\text { 1-methylhistidine } \\
\text { 3-methylhistidine } \\
\text { Ornithine } \\
\text { Lysine } \\
\text { Arginine }\end{array}$ & $\begin{array}{l}0.89 \\
1.80 \\
<.10 \\
1.57 \\
4.64 \\
0.24 \\
6.38 \\
5.08 \\
3.03 \\
1.80 \\
2.26 \\
1.49 \\
0.79 \\
0.43 \\
5.73 \\
1.55 \\
3.03 \\
1.60 \\
0.32 \\
<.10 \\
1.22 \\
5.50 \\
2.30\end{array}$ & $\begin{array}{l}- \\
1.48 \\
<.10 \\
1.92 \\
4.42 \\
0.39 \\
8.45 \\
6.00 \\
3.44 \\
1.63 \\
2.39 \\
1.59 \\
1.26 \\
0.28 \\
6.00 \\
2.55 \\
4.48 \\
1.33 \\
<.10 \\
<.10 \\
1.50 \\
7.22 \\
3.12\end{array}$ & $\begin{array}{c}0.31 \\
0.82 \\
0 \\
0.09 \\
1.08 \\
0.09 \\
3.44 \\
3.34 \\
2.02 \\
0.83 \\
0.97 \\
-0.02 \\
0.49 \\
-0.04 \\
3.53 \\
0.83 \\
1.90 \\
0.27 \\
0.06 \\
0 \\
0.29 \\
2.57 \\
0.90\end{array}$ & $\begin{array}{l}\overline{0.83} \\
0 \\
0.37 \\
2.22 \\
0.17 \\
5.94 \\
4.52 \\
2.71 \\
0.76 \\
1.28 \\
0.20 \\
0.96 \\
0.02 \\
4.36 \\
1.57 \\
3.55 \\
0.42 \\
0 \\
0 \\
0.72 \\
4.52 \\
2.05\end{array}$ \\
\hline
\end{tabular}

* Calculated as glycine (cf. footnote to Table III).

both the qualitative and quantitative distribution of amino acids in normal fasting urine were found, on an hourly basis, to be similar to, not lower than the 24-hour values already published (5). Moreover, a sample of urine collected three hours after ingesting $50 \mathrm{Gm}$. of casein (as Protinal) ${ }^{2}$ still gave the usual amino acid distribution and quantitative values not higher than some of the normals previously investigated.

In contrast to the normal, however, both the qualitative distribution and the quantitative level of the urinary amino acids in Wilson's disease were found to be markedly dependent upon the dietary intake of protein, a finding somewhat at variance with a conclusion of Cooper, Eckhardt, Faloon, and Davidson (3). The data presented in Figures 4 and 5 of the preceding paper (7), and in Table V of this paper show the levels of amino acids in the fasting urine from two patients with Wilson's disease, and in a urine specimen collected from one of these patients after the ingestion of $50 \mathrm{Gm}$. of casein. The amino acid distribution in fasting urine

2 A micropulverized casein-carbohydrate mixture, The National Drug Company, Philadelphia. 


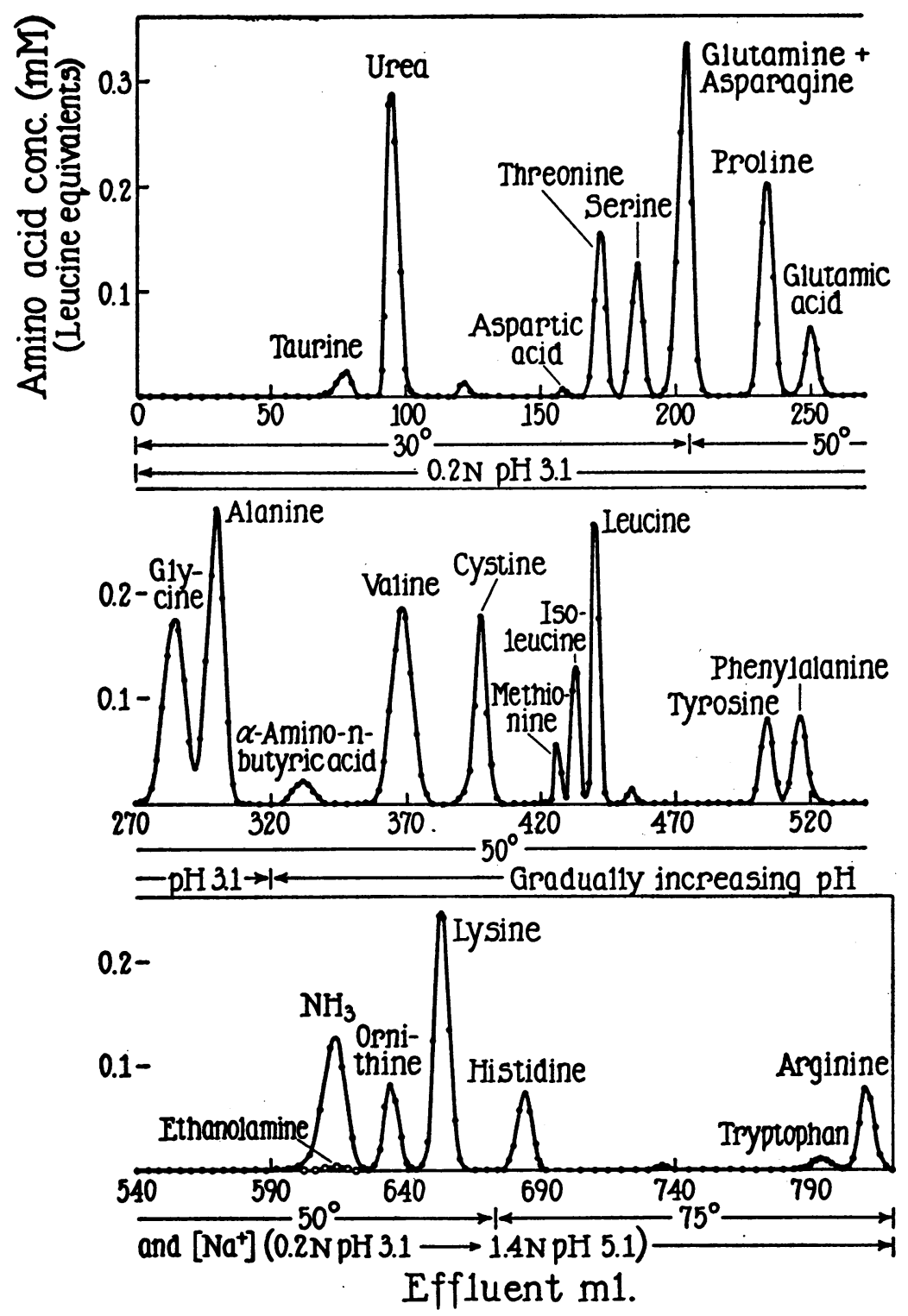

Fig. 2. Chromatographic Separation of Amino Acids from the Plasma of a Patient with Wilson's Disease, Patient 7, Table III

The column of Dowex 50 (4 per cent cross-linking), $0.9 \times 150 \mathrm{~cm}$., was operated in the sodium form with buffers of the $\mathrm{pH}$ and temperature indicated as eluants. A sample of $8.3 \mathrm{cc}$. of deproteinized plasma was chromatographed. The open circles under the ammonia peak indicate the quantity of ninhydrinpositive material (ethanolamine) remaining in these fractions after they had been rendered alkaline and exposed to reduced pressure to remove ammonia. Citrulline, shown by Archibald (21) to be present in plasma to the extent of about $0.50 \mathrm{mg}$. per $100 \mathrm{cc}$., emerges with glycine in these chromatograms.

is quite different from that observed with normal subjects or from that shown by the 24-hour specimens given in Table I. For glutamic acid, aminoadipic acid, aminobutyric acid, valine, leucine, isoleucine, methionine, proline, phenylalanine, ornithine, and arginine, the levels are essentially normal. Increased amounts of threonine, serine, asparagine, glycine, and cystine (possibly also 
glutamine) are present, and somewhat increased quantities of alanine, tyrosine, histidine, and lysine. Taurine excretion is notably small.

After the ingestion of $50 \mathrm{Gm}$. of protein, however, there is a large rise in all of the urinary amino acids with the exception of aminobutyric acid, taurine, ornithine, and the methylhistidines. Alanine, valine, leucine, threonine, cystine, proline, tyrosine, lysine, and arginine increase the most. The pattern of the rise in urinary amino acid excretion can be correlated only partly with the amino acid composition of the casein fed.

In view of the results obtained with urine, the response of the plasma amino acid level in Wilson's disease to the ingestion of protein was determined. Fasting blood was withdrawn from Patient 7 at the same time as the fasting urine sample (Table V) was taken, and another blood sample was taken two hours after the ingestion of $50 \mathrm{Gm}$. of casein. The post-protein urine sample was collected during a three-hour period beginning at the time of the ingestion of the casein. Blood samples from a normal individual, were taken in the same fashion.

The results of the analyses of fasting and postprandial plasma in the normal subject and in the patient are given in Table VI. In both individuals the plasma levels of almost all amino acids rise after ingesting casein. The levels of taurine, the methylhistidines (too low in amount to be detectable in Wilson's disease plasma), and aminobutyric acid remain constant, or nearly so, which is not surprising since they are not constituent amino acids of casein. Ornithine, on the other hand, which is not normally considered to be a component of casein, increases in amount just as do some of the other amino acids. Cystine, however, which comprises only 0.34 per cent of the casein fed, does not alter at all in concentration in the normal subject, but rises slightly in the patient. The increase in the remaining amino acids reflects to some degree, but not in detail, the amino acid composition of the casein fed. Thus the greatest increase is shown by valine, leucine, proline, tyrosine, and lysine, which are also present in fairly large amounts in casein, but a relatively much smaller proportionate increase is observed for glycine, serine, and histidine. The pattern of the rise is similar in both the normal subject and the patient with Wilson's disease. Although the extent of the increase is uniformly greater for all amino acids in the patient with Wilson's disease, the total quantity of amino acids is similar in the two individuals, and the observed variations are not greater than those to be expected among normal individuals. The conclusion at this juncture seems warranted, therefore, that the amino acid picture in the blood in Wilson's disease is close to normal.

\section{DISCUSSION}

This communication, together with similar findings reported previously $(3,4)$ indicate that a renal lesion exists in Wilson's disease. It would appear difficult to explain on any other basis the existence of aminoaciduria in the presence of a normal qualitative and quantitative distribution of amino acids in the plasma, both fasting and postprandial. Although aminoaciduria is a frequent concomitance, this abnormality is absent in one undoubted case of the disease (Patient 2, Table I) out of the six examined in detail. Other cases of Wilson's disease exhibiting a normal urinary output of amino acids have been reported (3). The conclusion seems justifiable that, whatever the cause, the aminoaciduria is a secondary consequence of some other basic disturbance. This basic disturbance may well be connected with copper metabolism $(7,17,18)$, since all the patients in the present group ( 7 ), including Patient 2 , reveal a high urinary and low plasma level of copper. If the disease progresses, however, the kidney may become involved, and an aminoaciduria might then result. It appears likely that the excretion of all of the amino acids is not affected to the same extent nor at the same time, but that the urinary amino acid pattern gradually changes from one which is quantitatively and qualitatively relatively insensitive to dietary protein intake, to one which reflects to a much greater degree the level of protein in the

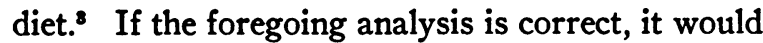
be expected that the urinary amino acid pattern in

8 It is of interest that the relative amounts of ten of the amino acids excreted by Patients 1, 3, 4 are in the approximate ratio $1: 1.7: 1$. For example, the excretion of glycine is $520 \mathrm{mg}$. for Patient $1,960 \mathrm{mg}$. for Patient 3, and $530 \mathrm{mg}$. for Patient 4 , a ratio of $1: 1.84: 1.02$. This constancy of ratio for so many amino acids might reflect the fact that all three patients were on the same ward and received the same diet. The urine specimens for two of the patients ( 1 and 3 ) were collected on the same day, for the third patient, one week later. 
a group of individuals suffering from Wilson's disease might vary markedly depending upon the state of the disease and the composition of the diet. Evidence for such variation has been presented in this paper.

Although a renal lesion in Wilson's disease is indicated, the nature of this lesion cannot be delineated with much certainty. Some of the findings are obviously compatible with a "lowered kidney threshold" for amino acids, an explanation that has already been advanced (4). Other features are not so readily explained on this basis. For example, judging from the urinary picture, the amino acids most seriously implicated in Wilson's disease are threonine and cystine. Cystine frequently appears in abnormal quantities in the urine, as has been pointed out by Dent and Harris (2), and is found associated with many different amino acids. In cystinuria the accompanying amino acids are lysine, ornithine, and arginine $(12,13)$. In Wilson's disease, on the other hand, despite an increased excretion of cystine, lysine, and sometimes ornithine, the arginine level is frequently normal. If, as has been suggested by Dent and Rose (12), these four amino acids are reabsorbed in the tubule by a common mechanism, which is deficient in cystinuria, then these four amino acids should appear together whenever this hypothetical block is present. In one instance, Patient 5 (Table I), cystine, arginine, lysine, and ornithine are all present in grossly abnormal quantities, but in the other cases, the parallelism with cystinuria does not hold.

Cystine is an amino acid which seems to appear in abnormal quantities in the urine in many different conditions (19), and associated with many different amino acids. It may be that a high urinary level of cystine does not indicate failure of tubular reabsorption, but reflects a rather more general kidney dysfunction. If cysteine and glutathione $\mathrm{SH}$ groups are essential to normal cellular function, the appearance of cystine in the urine may merely indicate a disturbance in some oxidationreduction mechanism in the kidney.

It would appear that a failure of tubular reabsorption could not account for the lower than normal excretion observed for several amino acids in many of the patients. The level of taurine is frequently lower than normal, as it is also in cys- tinuria (13), and the methylhistidines also seem to be excreted in less than normal quantities.

\section{SUMMARY}

1. The amino acid distribution in 24-hour specimens of the urine of patients with Wilson's disease has been investigated by chromatography on columns of the ion exchange resin Dowex 50. Of six cases examined, five exhibited a widespread and massive aminoaciduria. One undoubted case of the disease showed an almost normal excretion of amino acids. In general it appears that the highest levels of excretion relative to the normal are reached by threonine and cystine, which may be elevated twenty-fold. The levels of serine, glycine, asparagine (and probably also glutamine) valine, tyrosine, and lysine may rise 5 to 10 fold while histidine, ornithine, and phenylalanine occur at 2 to 4 times the normal level. Two amino acids not encountered in normal urine, namely proline and citrulline, appear in considerable quantities in many cases. The amounts of aminoadipic acid, methionine, isoleucine, leucine, and arginine seem to be the least abnormal, while on the average there appears to be a diminished excretion of taurine, 1-methylhistidine, and 3-methylhistidine.

2. Amino acids in conjugated linkages exist in Wilson's disease urine in quantities about double those obtained from normal urine. There is thus a smaller proportional elevation in the amount of conjugated amino acids than found for the free amino acids.

3. As determined by chromatography on Dowex 50 , the amino acid distribution in the plasma of subjects with Wilson's disease is qualitatively and quantitatively normal, both in the fasting state and after a protein meal.

4. Quantitatively and qualitatively, the amino acid levels in the urine of normal individuals are relatively insensitive to the amount of protein in the diet. Moreover, fasting urine in the normal has about the same amino acid composition found for the 24-hour specimen. In Wilson's disease, on the other hand, the level of urinary amino acids is quite sensitive to the protein intake, and fasting urine has a very different amino acid composition from that found for the 24-hour specimen.

5. The available evidence indicates clearly that the aminoaciduria in Wilson's disease is a result 
of a renal lesion. This symptom appears, however, to be a secondary consequence of some other basic disturbance that may well be connected with copper metabolism. Hence the urinary amino acid pattern in a group of individuals suffering from Wilson's disease might vary markedly depending both upon the state of the disease and the composition of the diet.

\section{ACKNOWLEDGMENT}

The authors would like to acknowledge with gratitude the expert technical assistance of Mrs. Gertrude C. Carey.

\section{REFERENCES}

1. Uzman, L., and Denny-Brown, D., Amino-aciduria in hepato-lenticular degeneration (Wilson's disease). Am. J. Med. Sc., 1948, n.s. 215, 599.

2. Dent, C. E., and Harris, H., The genetics of 'cystinuria'. Ann. Eugenics, 1951, 16, 60.

3. Cooper, A. M., Eckhardt, R. D., Faloon, W. W., and Davidson, C. S., Investigation of the aminoaciduria in Wilson's disease (hepatolenticular degeneration): Demonstration of a defect in renal function. $\mathrm{J}$. Clin. Invest., 1950, 29, 265.

4. Matthews, W. B., Milne, M. D., and Bell, M., The metabolic disorder in hepato-lenticular degeneration. Quart. J. Med., 1952, n.s. 21, 425.

5. Stein, W. H., A chromatographic investigation of the amino acid constituents of normal urine. J. Biol. Chem., 1953, 201, 45.

6. Stein, W. H., and Moore, S., The amino acids of human blood plasma. To be published.

7. Bearn, A. G., and Kunkel, H. G., Abnormalities of copper metabolism in Wilson's disease and their relationship to the aminoaciduria. J. Clin. Invest., 1954, 33, 400.

8. Craig, L. C., Gregory, J. D., and Hausmann, W., Versatile laboratory concentration device. Anal. Chem., 1950, 22, 1462.
9. Moore, S., and Stein, W. H., Chromatography of amino acids on sulfonated polystyrene resins. J. Biol. Chem., 1951, 192, 663.

10. Moore, S., and Stein, W. H., Chromatography of amino acids on sulfonated polystyrene resins (Dowex 50 4 4). To be published.

11. Tallan, H. H., Stein, W. H., and Moore, S., 3-methylhistidine, a new amino acid from human urine. $J$. Biol. Chem., 1954, 206, 825.

12. Dent, E. C., and Rose, G. A., Amino acid metabolism in cystinuria. Quart. J. Med., 1951, n.s. 20, 205.

13. Stein, W. H., Excretion of amino acids in cystinuria. Proc. Soc. Exper. Biol. \& Med., 1951, 78, 705.

14. Van Slyke, D. D., MacFadyen, D. A., and Hamilton, P. B., The gasometric determination of amino acids in urine by the ninhydrin carbon dioxide method. J. Biol. Chem., 1943, 150, 251.

15. Kirsner, J. B., Sheffner, A. L., and Palmer, W. L., Studies on amino acid excretion in man. III. Amino acid levels in plasma and urine of normal men fed diets of varying protein content. J. Clin. Invest., 1949, 28, 716.

16. Eckhardt, R. D., and Davidson, C. S., Urinary excretion of amino acids by a normal adult receiving diets of varied protein content. J. Biol. Chem., 1949, 177, 687.

17. Glazebrook, A. J., Wilson's disease. Edinburgh M. J., 1945, 52, 83.

18. Denny-Brown, D., and Porter, H., The effect of BAL (2,3-dimercaptopropanol) on hepatolenticular degeneration (Wilson's disease). New England J. Med., 1951, 245, 917.

19. Dent, C. E., and Walshe, J. M., Amino-acid metabolism in liver disease. Liver Disease, A Ciba Foundation Symposium, Sherlock, S., ed., Philadelphia, The Blakiston Co., 1951, p. 22.

20. Chinard, F. P., Photometric estimation of proline and ornithine. J. Biol. Chem., 1952, 199, 91.

21. Archibald, R. M., Determination of citrulline and allantoin and demonstration of citrulline in blood plasma. J. Biol. Chem., 1944, 156, 121. 